\title{
PERANCANGAN JARINGAN LTE FDD DI TOL SOREANG-PASIR KOJA MENGGUNAKAN SOFTWARE PLANNING
}

\section{DESIGN OF LTE FDD NETWORK AT SOREANG-PASIRKOJA HIGHWAY USING SOFTWARE PLANNING}

\author{
Yuyun Siti Rohmah ${ }^{1}$, Dwi Andi Nurmantris ${ }^{2}$ \\ 1,2Fakultas Ilmu Terapan, Universitas Telkom \\ 1yuyunsitirohmah@ telkomuniversity.ac.id, ${ }^{2}$ dwiandi@telkomuniversity.ac.id
}

\begin{abstract}
Abstrak
Teknologi komunikasi seluler Long Term Evolution saat ini berkembang pesat di Indonesia, salah satunya di kota Bandung. Namun masih terdapat beberapa area yang kualitas jaringannya masih di bawah standar Key Performance Indikator (KPI) , salah satunya adalah area tol Soreang Pasir Koja. Tol sepanjang $10.6 \mathrm{Km}$ tersebut merupakan tol yang baru dioperasikan sekitar akhir 2017 lalu. Maka pada penelitian ini dilakukan pengukuran berupa drive test dan analisis serta simulasi perencanaan untuk jaringan LTE FDD di area tol Soreang Pasir koja berdasarkan cakupan area dan kapasitas menggunakan software planning pada frekuensi $1800 \mathrm{MHz}$. Berdasarkan hasil perhitungan dan simulasi, untuk meningkatkan parameter kualitas sinyal di tol Soreang Pasirkoja dibutuhkan tambahan sebanyak 10 site dan menghasilkan 99.9\% nilai RSRP sudah diatas -102 $\mathrm{dBm}$, SINR 99.97\% sudah diatas 3 dB. Sedangkan untuk throughput rata-rata sebesar 34.34 Mbps.
\end{abstract}

\section{Kata kunci : LTE, Coverage, Capacity}

\begin{abstract}
Long Term Evolution (LTE) communication technology Cellular is currently growing rapidly in Indonesia, one of them is in the city of Bandung. However, there are still some areas where the quality of the network is still below the standard Key Performance Indicator (KPI), such as at Soreang Pasir Koja highway. It has about $10.6 \mathrm{~km}$ that is operated in last of 2017. Therefore, in this research, the LTE FDD network planning is done from the coverage of area and capacity using software planning at $1800 \mathrm{MHz}$. Based on the calculation and simulation, to improve the signal quality parameters in Soreang - Pasirkoja toll needed as much as 10 sites and produce $99.9 \%$ RSRP value above $-102 \mathrm{dBm}, 99.97 \%$ SINR above 3 $\mathrm{dB}$. and the average throughput $34.34 \mathrm{Mbps}$.
\end{abstract}

Keywords: LTE, Coverage, Capacity

\section{PENDAHULUAN}

Sistem komunikasi seluler di Indonesia berkembang yang sangat pesat. Long Term Evolution (LTE) adalah teknologi seluler generasi ke 4 berdasarkan standar 3GPP yang sudah diterapkan di Indonesia. Teknologi LTE dapat memberikan kecepatan akses data hingga 300 Mpbs untuk arah downlink sedangkan75 Mbps untuk arah uplink. LTE mendukung aplikasi suara, data, video sampai IP TV. Keunggulan dari LTE dibanding teknologi generasi sebelumnya diantaranya kecepatan data yang ditawarkan LTE, cakupan area dan kapasitas dari layanan teknologi tersebut lebih besar, dapat menggunakan multiple antena, penggunaan bandwidth yang flexible serta dapat terkoneksi dengan jaringan yang ada sebelumnya. Teknologi akses yang digunakan LTE adalah OFDMA dan SCFDMA untuk arah downlink dan uplink. Teknologi LTE menggunakan teknik antena MIMO (Multi Input Multi Output) dan Sistem Orthogonal Frequency Division Multiplexing (OFDM) yang merupakan salah satu kunci dari Teknologi LTE [1]. Teknik multicarrier OFDM menghasilkan performansi LTE tahan terhadap kondisi frequency selective fading. Selain itu Teknologi MIMO pada sistem LTE mampu meningkatkan data rate [2]. 
Di Jawa barat khususnya di Bandung, teknologi LTE telah di implementasikan hampir di semua area. Namun ada beberapa wilayah yang kualitas jaringannya masih di bawah standar Key Performance Indicator (KPI) seperti di Tol Soreng Pasirkoja. Area tol tersebut baru beroperasi sekitar akhir tahun 2017. Performansi jaringan seluler di area ini masih belum optimal. Hal tersebut terlihat dari hasil drive test yang didapatkan. Nilai RF Signal quality untuk parameter RSRP, SINR dan Throughput adalah 0.68 $\%$ untuk nilai RSRP diatas $-102 \mathrm{dBm}$, sekitar $41.88 \%$ diatas $3 \mathrm{~dB}$ untuk nilai SINR dan $2.51 \%$ nilai throughput di atas $12 \mathrm{Mbps}$. Dengan melihat performasi jaringan di tol tersebut maka dibutuhkan suatu perencanaan jaringan LTE yang bisa memenuhi kebutuhan user pada area tersebut. Oleh karena itu, pada penelitian ini dilakukan pengukuran berupa drive test dan analisis serta simulasi perencanaan jaringan Long Term Evolution- Frequency Division Duplex (LTE-FDD) menggunakan software planning yang meliputi perencanaan coverage dan capacity. Perencanaan yang akan dilakukan menggunakan frekuensi $1800 \mathrm{MHz}$. Dengan melihat Perencanaan jaringan LTE pada [3] yang dilakukan pada frekuensi tersebut yang ditinjau dari dua sisi yaitu kapasitas dan area cakupan, kemudian analisa cakupan area dan kapasitas LTE untuk Wireles private network [4] menyimpulkan bahwa penggunaan frekuensi $1800 \mathrm{MHz}$ cocok digunakan di area urban. Pada penelitian [5] menyebutkan bahwa site mikro yang dikombinasikan dengan site makro dapat memberikan cakupan yang lebih baik.

\section{PERENCANAAN JARINGAN LTE-FDD}

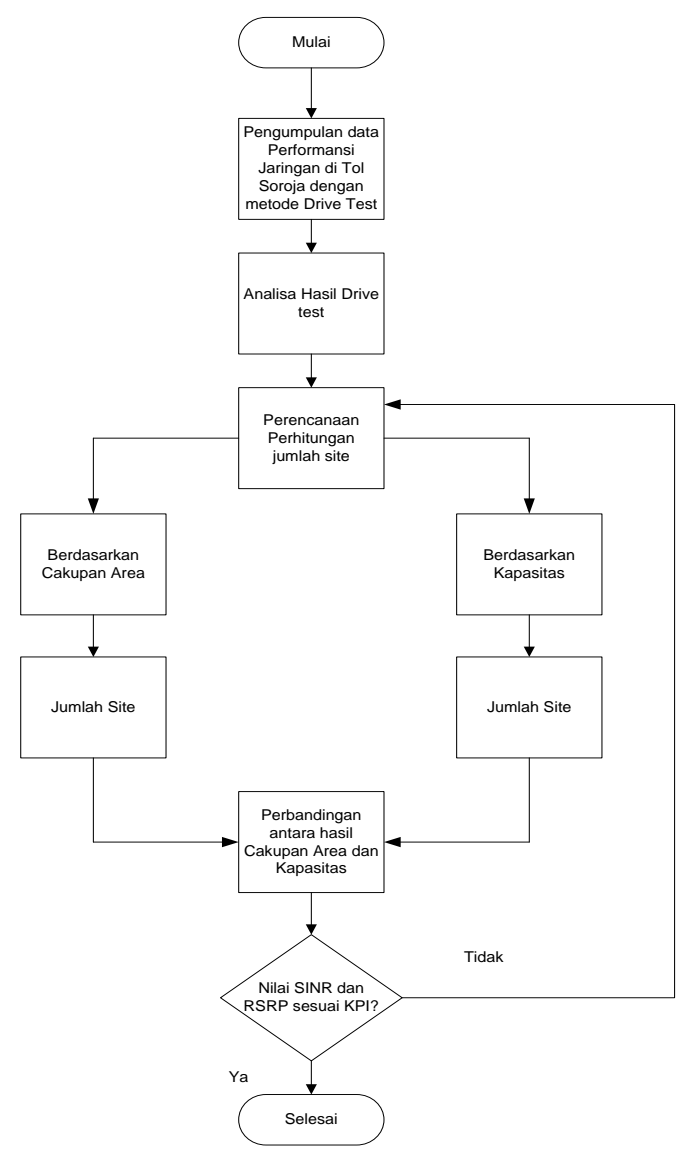

Gambar 1. Diagram Alir Perencanaan

Alur perencanaan jaringan LTE-FDD di area tol Soreang pasir koja bisa dilihat pada gambar 1. Tahap-tahap perancangan dimulai dengan mengumpulkan data performansi jaringan dengan metode drive test yang kemudian dianalisa untuk dilihat permasalahan yang ada. Drive test 
merupakan proses pengujian performansi sinyal yang dilakukan secara real di lapangan [6]. Langkah selanjutnya adalah melakukan perencanaan berdasarkan cakupan area dan kapasitas untuk menentukan jumlah Site. Jumlah Site yang didapat kemudian dijadikan input untuk proses simulasi sehingga didapatkan parameter kualitas RF yang sesuai dengan KPI.

\subsection{Analisa Hasil Drive test}

Hasil drive test awal terhadap parameter RSRP, SINR dan nilai Througput diperlihatkan pada gambar 2, 3 dan 4 .

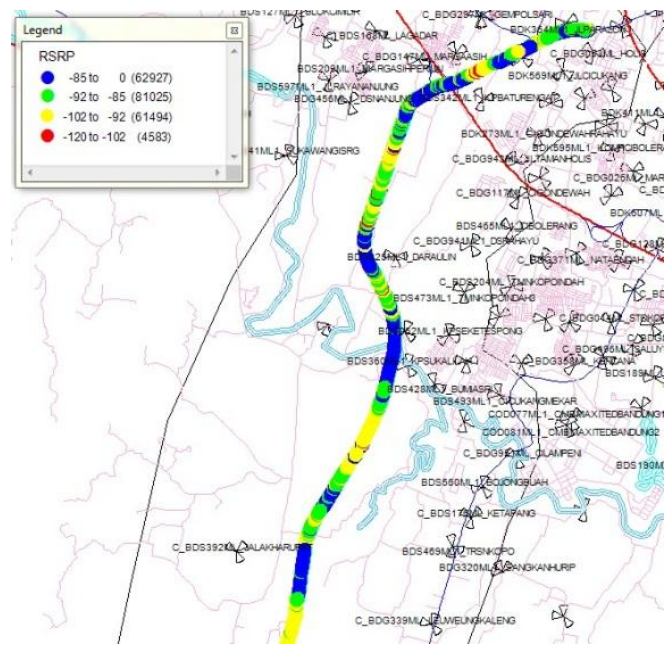

Gambar 2. Hasil Drive Test untuk Parameter RSRP

RSRP (Reference Signal Received Power) merupakan Parameter performansi sistem yang menggambarkan level daya terima UE (User Equipment) pada jaringan LTE. Dari Hasil Drive test didapatkan $0.68 \%$ untuk nilai RSRP diatas $-102 \mathrm{dBm}$. Hal ini dikarenakan mobility dari user berada pada kecepatan rata-rata antara $60 \mathrm{~km}$ per jam sampai $80 \mathrm{~km}$ per jam yang menyebabkan proses terjadinya hand over lebih sering dan hal ini juga dikarenakan belum optimalnya jumlah site yang melayani di area tol tersebut yang menyebabkan kegagalan proses hand over. Prosentase nilai RSRP tersebut jauh dari standar KPI yang ditentukan, seperti terlihat pada tabel 1, sehingga pada penelitian ini perencanaan LTE berdasarkan kapasitas dan cakupan area harus meningkatkan nilai RSRP.

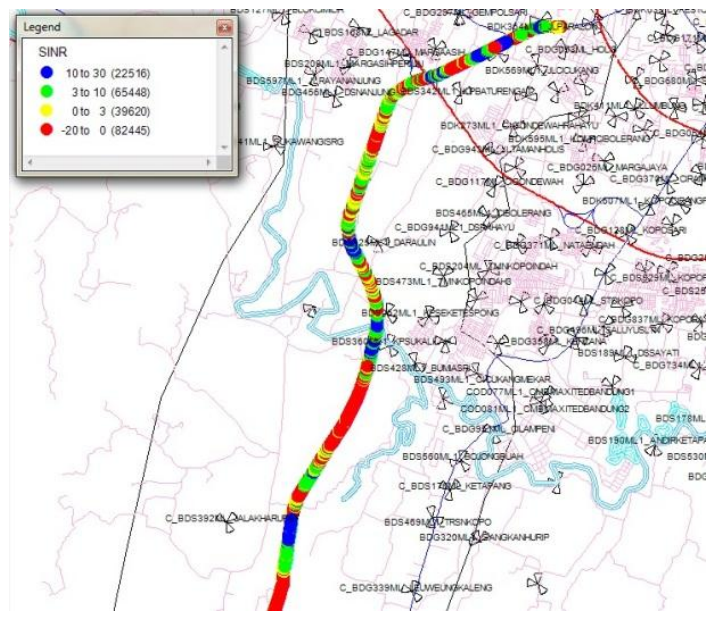

Gambar 3. Hasil Drive Test untuk Parameter SINR 
Parameter SINR (Signal to Interference and Noise Ratio) merupakan perbandingan antara sinyal yang diinginkan terhadap sinyal interferensi dan noise. SINR yang baik menunjukan performansi jaringan yang baik pula. Berdasarkan standar KPI, nilai SINR yang baik adalah diatas $5 \mathrm{~dB}>90 \%$. Dari Hasil drive test didapatkan $41.88 \%$ yang nilainya di atas $3 \mathrm{~dB}$ hal ini juga tentunya masih jauh dari KPI.

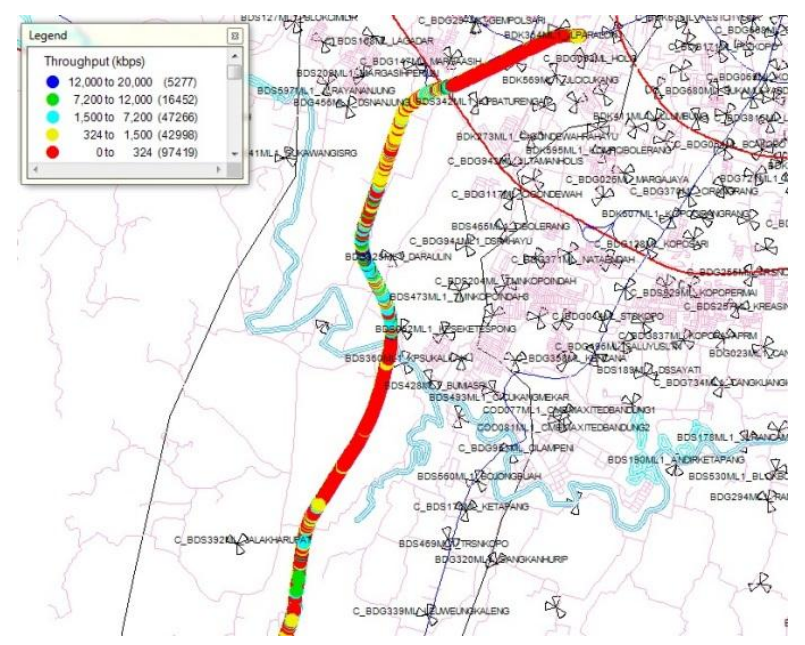

Gambar 4. Hasil Drive Test untuk Parameter Througput

Gambar 4 memperlihatkan hasil dari proses drive test untuk parameter throughput. Throughput merupakan parameter yang menyatakan kecepatan akses yang bisa didapatkan user [7]. Parameter tersebut merupakan kecepatan data minimal yang diterima user pada saat jam sibuk. Dari Hasil drivetest didapatkan hanya $2.51 \%$ yang nilainya diatas $12 \mathrm{Mbps}$, nilai sangat jauh dari standar KPI.

Tabel 1 Parameter KPI yang digunakan

\begin{tabular}{|l|c|c|}
\hline \multicolumn{1}{|c|}{ Objective } & Parameter & Target KPI \\
\hline Coverage & RSRP & $90 \% \geq-100 \mathrm{dBm}$ \\
\hline Kualitas Sinyal & SINR & $90 \% \geq 5 \mathrm{~dB}$ \\
\hline Service Integrity & Throughput & $\geq 12 \mathrm{Mbps}$ \\
\hline
\end{tabular}

\subsection{Perhitungan Jumlah Site}

Sebelum melakukan perencanaan dan simulasi, perlu disampaikan terlebih dulu parameter perencanaan jaringan LTE-FDD yang digunakan pada penelitian ini. Parameter tersebut bisa dilihat pada tabel 2.

Tabel 2 Spesifikasi Perancangan Jaringan LTE

\begin{tabular}{|l|c|}
\hline Morphology & Urban \\
\hline Duplex Mode & FDD \\
\hline Channel Bandwidth $(\mathrm{Mhz})$ & 10 \\
\hline Carrier frequency $(\mathrm{MHz})$ & 1800 \\
\hline
\end{tabular}

\subsubsection{Perhitungan Jumlah Site berdasarkan Kapasitas}

Perhitungan pendekatan secara kapasitas dilakukan untuk mengetahui banyaknya user yang dapat dilayani oleh enodeB [8] . Tahap pertama dalam perencanaan jaringan LTE berdasarkan perhitungan kapasitas adalah menentukan estimasi jumlah pelanggan beberapa tahun mendatang (forecasting) dengan menggunakan persamaan (1) 
$P_{i}=P_{o}(1+G F)^{i}$

Pi merupakan estimasi dari jumlah penduduk pada tahun ke-i, GF merupakan faktor pertumbuhan dari penduduk di area tertentu sedangkan Po adalah jumlah penduduk pada tahun ke saat ini. Total user yang dihitung sebanyak 10500, diperoleh dari estimasi panjang tol sekitar $10.5 \mathrm{Km}$, panjang rata-rata mobil sekitar 5 meter, dan jumlah penumpang rata-rata tiap mobil sekitar 5 orang. Kemudian untuk tahap selanjutnya adalah menentukan service model, traffic model yang disajikan pada tabel 3 dan 4 .

Throughput (Kbit) $/$ session $=$

Session Time(s)x Session duty Ratio x Bearer Rate ( kbps)x [1/(1 - BLER)]

Single user throughput $=$

$$
\left[\left(\frac{\text { Througput }}{\text { session }}\right) \times B H S A x \text { Penetration } \mathrm{x}(1+\text { Peak to Average Ratio })\right] / 3600
$$

DL Cell Capacity + CRC $=(168-36-12) \times($ Code bits $) x($ Code Rate $) \times N r b x$ Cx1000

UL Cell Capacity + CRC $=(168-24) x($ Code bits $) x($ Code rate $) x$ NrbxCx1000

Dengan menggunakan persamaan (2) dan (3) didapatkan nilai throughput per session dan single user throughput pada tabel 5. Kemudian dengan menggunakan persamaan (4) dan (5) didapatkan kapasitas tiap site untuk LTE disajikan pada tabel 6.

Tabel 3. Service Model

\begin{tabular}{|c|c|c|c|c|c|c|c|c|c|c|}
\hline \multirow[b]{2}{*}{$\begin{array}{c}\text { Trafik } \\
\text { Parameter }\end{array}$} & \multicolumn{4}{|c|}{ Uplink } & \multicolumn{4}{|c|}{ Downlink } & \multirow{2}{*}{ 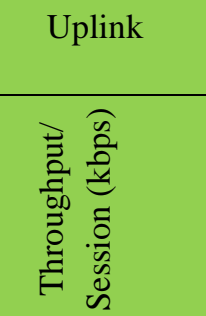 } & \multirow{2}{*}{ 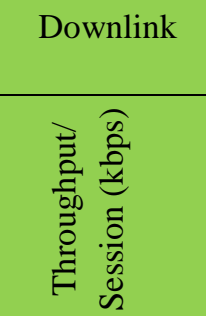 } \\
\hline & 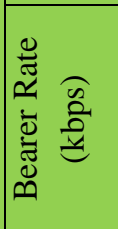 & 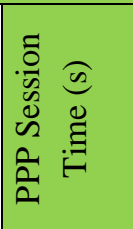 & 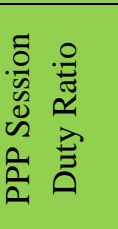 & $\frac{\frac{\alpha}{I I}}{\vec{\oplus}}$ & 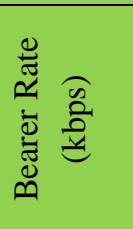 & 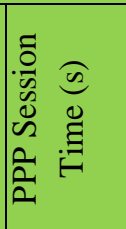 & 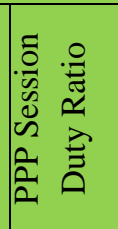 & $\frac{\underline{r}}{\vec{T}}$ & & \\
\hline VoIP & 26.9 & 80 & 0.4 & $1 \%$ & 26.9 & 80 & 0.4 & $1 \%$ & 869.4949 & 869.4949 \\
\hline Video Phone & 62.53 & 70 & 1 & $1 \%$ & 62.53 & 70 & 1 & $1 \%$ & 4421.3131 & 4421.3131 \\
\hline $\begin{array}{l}\text { Video } \\
\text { Converence }\end{array}$ & 62.53 & 1800 & 1 & $1 \%$ & 62.53 & 1800 & 1 & $1 \%$ & 113690.9091 & 113690.9091 \\
\hline $\begin{array}{l}\text { Real Time } \\
\text { Gaming }\end{array}$ & 31.26 & 1800 & 0.2 & $1 \%$ & 125.06 & 1800 & 0.4 & $1 \%$ & 11367.2727 & 90952.7273 \\
\hline $\begin{array}{l}\text { Streaming } \\
\text { Media }\end{array}$ & 31.26 & 3600 & 0.05 & $1 \%$ & 250.11 & 3600 & 0.95 & $1 \%$ & 5683.6364 & 864016.3636 \\
\hline $\begin{array}{l}\text { IMS } \\
\text { Signalling }\end{array}$ & 15.63 & 7 & 0.2 & $1 \%$ & 15.63 & 7 & 0.2 & $1 \%$ & 22.1030 & 22.1030 \\
\hline $\begin{array}{l}\text { Web } \\
\text { Browsing }\end{array}$ & 62.53 & 1800 & 0.05 & $1 \%$ & 250.11 & 1800 & 0.05 & $1 \%$ & 5684.5455 & 22737.2727 \\
\hline File Transfer & 140.7 & 600 & 1 & $1 \%$ & 750.34 & 600 & 1 & $1 \%$ & 85272.7273 & 454751.5152 \\
\hline Email & 140.7 & 50 & 1 & $1 \%$ & 750.34 & 50 & 1 & $1 \%$ & 7106.0606 & 37895.9596 \\
\hline $\begin{array}{l}\text { P2P File } \\
\text { Sharing }\end{array}$ & 250.1 & 1200 & 1 & $1 \%$ & 750.34 & 1200 & 1 & $1 \%$ & 303151.5152 & 909503.0303 \\
\hline
\end{tabular}


Tabel 4 Model Trafik

\begin{tabular}{|c|c|c|}
\hline \multirow[b]{2}{*}{ Traffic Behaviour } & \multicolumn{2}{|c|}{ Urban } \\
\hline & 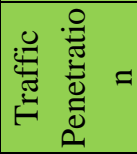 & 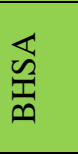 \\
\hline VoIP & $100 \%$ & 1.3 \\
\hline Video Phone & $20 \%$ & 0.16 \\
\hline Video Converence & $15 \%$ & 0.15 \\
\hline Real Time Gaming & $45 \%$ & 0.2 \\
\hline Streaming Media & $35 \%$ & 0.24 \\
\hline IMS Signalling & $30 \%$ & 4 \\
\hline Web Browsing & $100 \%$ & 0.62 \\
\hline File Transfer & $25 \%$ & 0.5 \\
\hline Email & $10 \%$ & 0.3 \\
\hline P2P File Sharing & $20 \%$ & 0.3 \\
\hline
\end{tabular}

Tabel 5 Nilai Single Throughput

\begin{tabular}{|l|c|c|}
\hline \multicolumn{1}{|c|}{ Traffik } & Uplink & Downlink \\
\hline VoIP & 1243.377778 & 1243.377778 \\
\hline Video Phone & 169.7784242 & 169.7784242 \\
\hline Video Conference & 3069.654545 & 3069.654545 \\
\hline Real Time Gaming & 1227.665455 & 9822.894545 \\
\hline Streaming Media & 572.9105455 & 87092.84945 \\
\hline IMS Signalling & 31.82836364 & 31.82836364 \\
\hline Web Browsing & 4229.301818 & 16916.53091 \\
\hline File Transfer & 12790.90909 & 68212.72727 \\
\hline E-mail & 255.8181818 & 1364.254545 \\
\hline P2P File Sharing & 21826.90909 & 65484.21818 \\
\hline Total & 45418.15329 & 253408.114 \\
\hline $\begin{array}{l}\text { Single User } \\
\text { Throughput (Kbps) }\end{array}$ & $\mathbf{1 2 . 6 1 6 1 5 3 6 9}$ & $\mathbf{7 0 . 3 9 1 1 4 2 7 8}$ \\
\hline
\end{tabular}


Tabel 6 Perhitungan Kapasitas Tiap Site

\begin{tabular}{|c|c|c|c|c|c|c|c|c|c|c|}
\hline $\begin{array}{l}\text { Modulat } \\
\text { ion }\end{array}$ & $\begin{array}{l}\text { Code } \\
\text { Bit }\end{array}$ & $\begin{array}{l}\text { Code } \\
\text { Rate }\end{array}$ & $\begin{array}{c}\text { SINR } \\
(\mathrm{min}) \\
(\mathrm{dB})\end{array}$ & $\begin{array}{c}\text { SINR } \\
\text { Probabili } \\
\text { ty }(\mathrm{Pn})\end{array}$ & $\begin{array}{c}\text { DL } \\
\text { Cell } \\
\text { Throug } \\
\text { hput } \\
\text { (bps) }\end{array}$ & $\begin{array}{c}\text { DL Cell } \\
\text { Throughp } \\
\text { ut (Mbps) } \\
(\mathrm{Rn})\end{array}$ & $\begin{array}{c}\text { DL Cell } \\
\text { Average } \\
\text { Throughput } \\
\text { (Mbps) }\end{array}$ & $\begin{array}{c}\text { UL Cell } \\
\text { Throug } \\
\text { hput } \\
\text { (bps) }\end{array}$ & $\begin{array}{c}\text { UL Cell } \\
\text { Throughp } \\
\text { ut (Mbps) } \\
(\mathrm{Rn})\end{array}$ & $\begin{array}{c}\text { UL Cell } \\
\text { Average } \\
\text { Throughput } \\
\text { (Mbps) }\end{array}$ \\
\hline $\begin{array}{c}\text { QPSK } \\
1 / 3 \\
\end{array}$ & 2 & 0.3 & $\begin{array}{c}-1,5- \\
0,3\end{array}$ & 0.28 & $\begin{array}{c}143999 \\
76\end{array}$ & 14.399976 & 4.0320 & $\begin{array}{c}863997 \\
6\end{array}$ & 8.639976 & 2.4192 \\
\hline $\begin{array}{c}\text { QPSK } \\
1 / 2 \\
\end{array}$ & 2 & 0.5 & $\begin{array}{c}0,3- \\
2 \\
\end{array}$ & 0.25 & $\begin{array}{c}239999 \\
76 \\
\end{array}$ & 23.999976 & 6.0000 & $\begin{array}{c}143999 \\
76\end{array}$ & 14.399976 & 3.6000 \\
\hline $\begin{array}{c}\text { QPSK } \\
2 / 3\end{array}$ & 2 & 0.67 & $\begin{array}{l}2- \\
4,5\end{array}$ & 0.17 & $\begin{array}{c}321599 \\
76\end{array}$ & 32.159976 & 5.4672 & $\begin{array}{c}192959 \\
76\end{array}$ & 19.295976 & 3.2803 \\
\hline $\begin{array}{c}16 \\
\text { QAM } 1 / 2\end{array}$ & 4 & 0.5 & $\begin{array}{c}4,5- \\
6\end{array}$ & 0.13 & $\begin{array}{c}479999 \\
76 \\
\end{array}$ & 47.999976 & 6.2400 & $\begin{array}{c}287999 \\
76 \\
\end{array}$ & 28.799976 & 3.7440 \\
\hline $\begin{array}{c}16 \\
\text { QAM } \\
2 / 3\end{array}$ & 4 & 0.67 & $\begin{array}{l}6- \\
8,5\end{array}$ & 0.1 & $\begin{array}{c}643199 \\
76\end{array}$ & 64.319976 & 6.4320 & $\begin{array}{c}385919 \\
76\end{array}$ & 38.591976 & 3.8592 \\
\hline $\begin{array}{c}16 \\
\text { QAM } \\
4 / 5\end{array}$ & 4 & 0.8 & $\begin{array}{l}8,5- \\
10,8\end{array}$ & 0.05 & $\begin{array}{c}767999 \\
76\end{array}$ & 76.799976 & 3.8400 & $\begin{array}{c}460799 \\
76\end{array}$ & 46.079976 & 2.3040 \\
\hline $\begin{array}{c}64 \\
\text { QAM } 1 / 2\end{array}$ & 6 & 0.5 & $\begin{array}{c}10,8- \\
12,5\end{array}$ & 0.01 & $\begin{array}{c}719999 \\
76\end{array}$ & 71.999976 & 0.7200 & $\begin{array}{c}431999 \\
76\end{array}$ & 43.199976 & 0.4320 \\
\hline $\begin{array}{c}64 \\
\text { QAM } \\
2 / 3 \\
\end{array}$ & 6 & 0.67 & $\begin{array}{c}12,5- \\
13,5\end{array}$ & 0.01 & $\begin{array}{c}964799 \\
76\end{array}$ & 96.479976 & 0.9648 & $\begin{array}{c}115775 \\
976\end{array}$ & 115.77598 & 1.1578 \\
\hline \multicolumn{7}{|c|}{ Cell Average Throughput $(\mathrm{MAC})=\sum \mathrm{Pn} \times \mathrm{Rn}$} & 33.6960 & & & 20.7965 \\
\hline \multicolumn{7}{|c|}{ Capacity per site } & 101.0879 & & & 62.3894 \\
\hline
\end{tabular}

Tabel 7 Perhitungan Site

\begin{tabular}{|l|r|r|}
\hline Parameter & \multicolumn{1}{|c|}{ Arah Uplink } & \multicolumn{1}{c|}{ Arah Downlink } \\
\hline Coverage Area & \multicolumn{2}{|c|}{$24.97 \mathrm{~km}^{2}$} \\
\hline Estimasi jumlah User & \multicolumn{2}{|c|}{10500} \\
\hline $\begin{array}{l}\text { Network Troughput } \\
\text { (Mbps) }\end{array}$ & 135.12 & 753.88 \\
\hline $\begin{array}{l}\text { Cell Average } \\
\text { Throughput (Mbps) }\end{array}$ & 20.22 & 33.7 \\
\hline Site Capacity $(\mathrm{Mbps})$ & 60.65 & 101.09 \\
\hline Number of Site & $\mathbf{2 . 2 3}$ & $\mathbf{7 . 4 6}$ \\
\hline Cell Coverage $\left(\mathrm{km}^{2}\right)$ & 11.21 & 3.35 \\
\hline
\end{tabular}

Dari hasil perhitungan berdasarkan kapasitas didapatkan jumlah site yang dibutuhkan berdasarkan kapasitas adalah sebanyak 8 site.

\subsubsection{Perhitungan Jumlah Site berdasarkan Cakupan Area}

Perhitungan berdasarkan cakupan area merupakan perhitungan untuk memastikan bahwa jaringan seluler memberikan layanan pada semua daerah cakupan .Hal pertama yang ditentukan adalah menghitung redaman sinyal baik pada sisi downlink atau pun sisi uplink. Penentuan redaman ini dinamakan Maximum Allowed Path Loss (MAPL), sehingga dari nilai MAPL ini dapat ditentukan estimasi radius suatu sel. 
$\operatorname{MAPL}(\mathrm{dB})=$ EIRP $(\mathrm{dBm})-$ Minimal Signal Reception $(\mathrm{dBm})-$ Penetration Loss $(\mathrm{dB})-$

Shadow Fade Margin $(\mathrm{dB})$

$\operatorname{EIRP}(\mathrm{dBm})=$

Subcarrier Power $(\mathrm{dBm})+$ Tx Antenna Gain $(\mathrm{dBi})-$

Tx Cable Loss $(\mathrm{dB})$

SubCarrier Power $(\mathrm{dBm})=$

MaxTotal Tx Power $(\mathrm{dBm})-10 \log ($ The number of Subcarrier to Distributed Power)

Min Signal Reception $(\mathrm{dBm})=$ Receiver sensitivity $(\mathrm{dBm})-\mathrm{Rx}$ Antenna Gain $(\mathrm{dBi})+$ Rx Cable Loss $(\mathrm{dB})+$ Interference Margin $(\mathrm{dB})$

Receiver Sensitivity $(\mathrm{dBm})=$ Thermal noise per subcarrier $(\mathrm{dBm})+$ Noise Figure $(\mathrm{dB})+$ Required SINR (dB)

Thermal noise per subcarrier $=10 \log (\mathrm{KxTxW})$

$\mathrm{K}$ adalah nilai konstanta Boltzman $\left(1.38 \times 10^{-23}\right.$ Joule $\left./{ }^{\circ} \mathrm{K}\right)$, T merupakan Temperature $\left(290^{\circ} \mathrm{K}\right)$ dan $\mathrm{W}$ merupakan Bandwidh (1 subcarrier $=15 \mathrm{KHz}$ ). Setelah ditentukan nilai MAPL maka tahap selanjutnya menentukan model propagasi yang digunakan. Pada Penelitian ini digunakan Model COST 231- Hatta [3], nilai redaman propagasi ditentukan dengan menggunakan persamaan (9).

$P_{L}=46.3+33.9(\log F c)-13.82 \operatorname{LogHb}-a(H m)+(44.9-6.55 \log H b) \log d+C M$

$\mathrm{a}(\mathrm{hm})=(1.1 \operatorname{LogFc}-0.7) \mathrm{hr}-(1.56 \operatorname{LogFc}-0.8)$

Penentuan luas sel dihitung menggunakan persamaan (14)

Luas sel $=1.95 \mathrm{x} \mathrm{d}^{2}$

$\sum$ site LTE $=\frac{\text { Luas area }}{\text { Luas Sel }}$

Trade off $=$ MAPL Capacity - MAPL Coverage 
Jurnal Elektro Telekomunikasi Terapan Juli 2018

Tabel 8. Perhitungan MAPL dan Radius Sel

\begin{tabular}{|c|c|c|}
\hline Parameter & Uplink & Downlink \\
\hline Teknik duplexing yang digunakan & \multicolumn{2}{|l|}{ FDD } \\
\hline Lebar Bandwidth kanal (MHz) & \multicolumn{2}{|l|}{10} \\
\hline Frekuensi Pembawa (MHz) & \multicolumn{2}{|l|}{1800} \\
\hline Pemancar & UE & eNodeB \\
\hline $\begin{array}{l}\text { Daya total maksimum yang dikirim } \\
(\mathrm{dBm})\end{array}$ & 23 & 43 \\
\hline Resource Block & 3 & 50 \\
\hline Jumlah Subcarrier & 36 & 600 \\
\hline Daya dari Subcarrier (dBm) & 7.437 & 15.218 \\
\hline Penguatan antena pemancar $(\mathrm{dBi})$ & 0 & 17 \\
\hline Redaman kabel pemancar (dB) & 0 & 0.5 \\
\hline $\begin{array}{l}\text { Nilai EIRP untuk masing-masing } \\
\text { subcarrier }(\mathrm{dBm})\end{array}$ & 7.437 & 31.718 \\
\hline Penerima & eNodeB & UE \\
\hline SINR $(\mathrm{dB})$ & -1.5 & -1.68 \\
\hline Nilai noise figure penerima $(\mathrm{dB})$ & 2.9 & 7 \\
\hline Sensitivitas dari penerima $(\mathrm{dBm})$ & -130.839 & -126.919 \\
\hline Penguatan antenna penerima $(\mathrm{dBi})$ & 17 & 0 \\
\hline Redaman perangkat penerima $(\mathrm{dB})$ & 2 & 2 \\
\hline Interference margin & 0.8 & 3.13 \\
\hline Daya sinyal terima minimum $(\mathrm{dBm})$ & -128.039 & -121.789 \\
\hline Redaman Penetrasi (dB) & 10 & 10 \\
\hline Shadow fading margin $(\mathrm{dB})$ & 4.24 & 4.24 \\
\hline MAPL (dB) & 138.236 & 139.268 \\
\hline Model Propagasi & \multicolumn{2}{|c|}{ Cost231-hatta } \\
\hline Tinggi antenna $e N o d e B(\mathrm{~m})$ & 30 & 30 \\
\hline Tinggi antenna UE (m) & 1.5 & 1.5 \\
\hline Frekuensi kerja(Mhz) & 1800 & 1800 \\
\hline $\mathrm{a}(\mathrm{Hm})$ & 0.04297 & 0.04297 \\
\hline Cell radius $(\mathrm{km})$ & 1.1432 & 1.2229113 \\
\hline
\end{tabular}

Tabel 9 Perhitungan Jumlah Site

\begin{tabular}{|c|c|c|c|}
\cline { 3 - 4 } Region & \multicolumn{1}{c}{$\begin{array}{c}\text { Large Region } \\
\left(\mathrm{km}^{2}\right)\end{array}$} & Cell Coverage $\left(\mathrm{km}^{2}\right)$ & Total Site \\
\hline Tol Soreang Pasirkoja & $\mathbf{2 4 . 9 7}$ & $\mathbf{2 . 5 5}$ & $\mathbf{9 . 8 0}$ \\
\hline
\end{tabular}

Dengan menggunakan persamaan (6) sampai dengan (15) jumlah site yang didapatkan berdasarkan pendekatan cakupan area adalah 10 site. Setelah didapatkan perhitungan dengan pendekatan kapasitas dan cakupan area, tahap selanjutnya adalah menghitung deviasi antara 2 perhitungan perencanaan tersebut sebagai trade of, jika trade of dibawah $5 \mathrm{~dB}$ asumsi perencanaan sudah tepat. [10] dengan persamaan (16). .tidak sama, maka, pada paper ini ditentukan jumlah site yang dibutuhkan adalah 10 site, karena jika menggunakan hasil pendekatan kapasitas yaitu 8 site, memang kapasitas sistem akan terpenuhi, namun area cakupan tidak terlayani maka akan berpengaruh terhadap nilai-nilai parameter RSRP, SINR serta Througput yang ingin dicapai.

\subsection{Analisa Hasil Simulasi}

Penentuan jumlah site yang diambil untuk proses simulasi adalah 10 site. Hal ini dikarenakan jika menggunakan hasil pendekatan kapasitas sebanyak 8 site, dari segi kapasitas sistem akan terpenuhi, namun area cakupan tidak terlayani maka akan berpengaruh terhadap nilainilai parameter RSRP, SINR serta Througput yang ingin dicapai. 10 site tersebut selanjutnya 
disimulasikan dengan menggunakan software planning yang diperlihatkan pada Gambar di bawah ini.

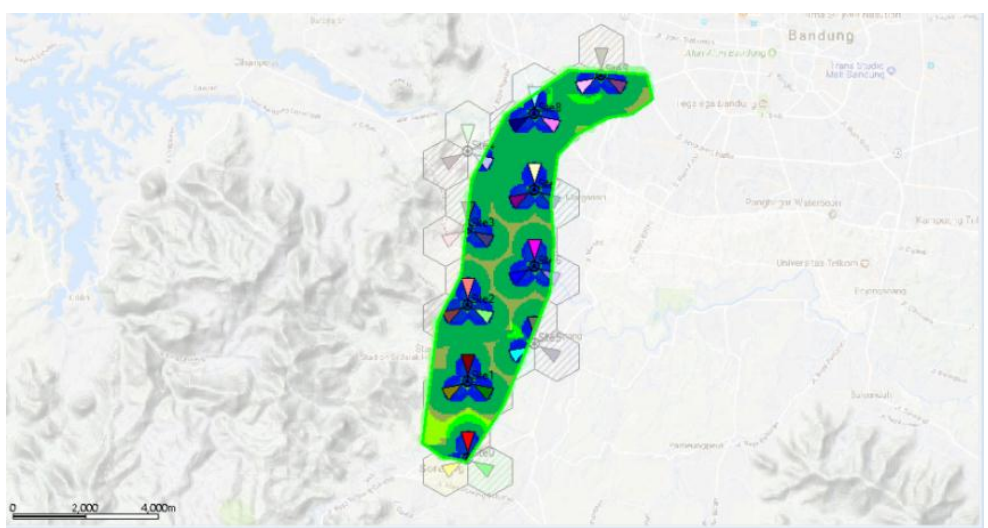

Gambar 5. Plotting Site Perencanaan Jaringan LTE FDD

Dari Hasil simulasi didapatkan rata-rata RSRP sekitar $-76.23 \mathrm{dBm}$ yang mana hampir 99.9\% nilai RSRP diatas $-102 \mathrm{dBm}$. Untuk parameter lainnya yaitu SINR berdasarkan hasil simulasi didapatkan SINR rata-rata sekitar $21.6 \mathrm{~dB}$ dengan $99.97 \%$ diatas $3 \mathrm{dBm}$. Sedangkan untuk throughput rata-rata sebesar $34.34 \mathrm{Mbps}$ dengan peningkatan sebesar $92.72 \%$. Untuk hasil simulasi ini diperlihatkan pada gambar histogram 6,7 dan 8 di bawah ini.

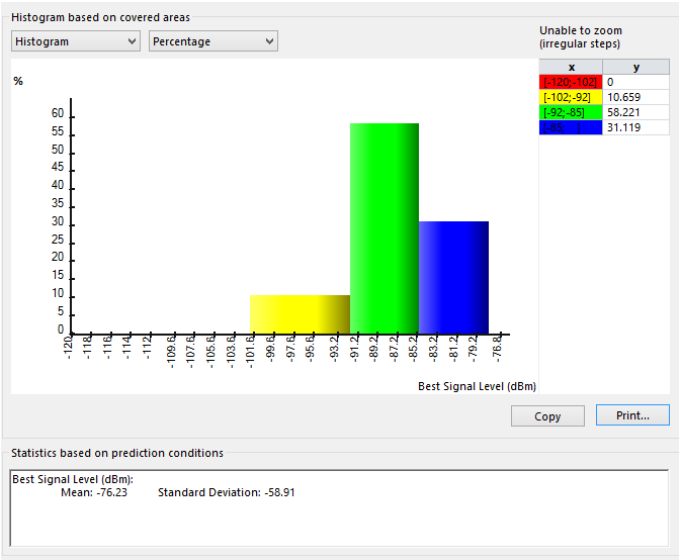

Gambar 6. Histogram Parameter RSRP setelah Perencanaan

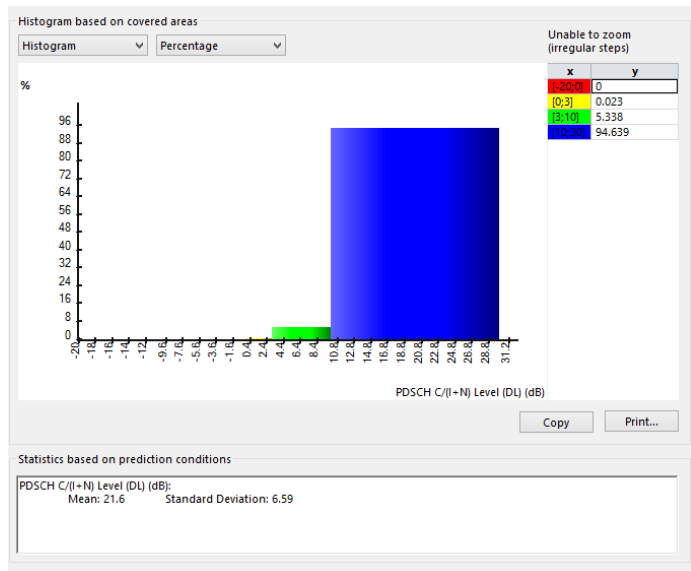

Gambar 7. Histogram Parameter SINR setelah Perencanaan 


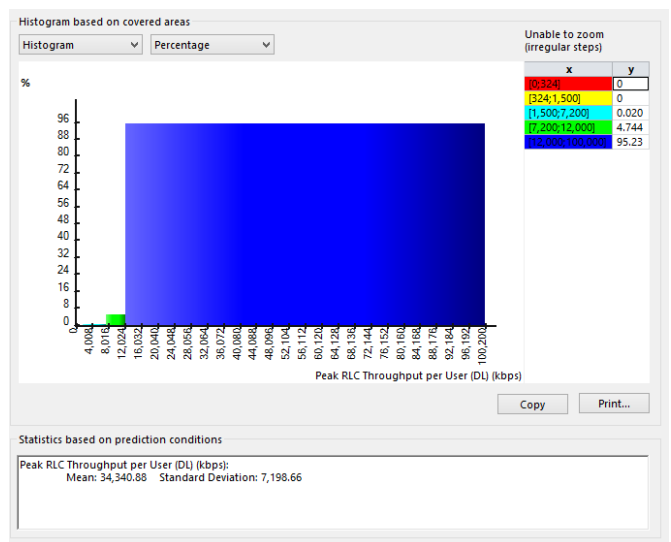

Gambar 8. Histogram Parameter Throughput setelah Perencanaan

\section{KESIMPULAN}

Berdasarkan hasil perhitungan dan simulasi menggunakan software planning untuk perencanaan cakupan area dan kapasitas dapat disimpulkan bahwa untuk meningkatkan parameter kualitas sinyal RSRP, SINR dan Throughput di tol Soreang Pasirkoja dibutuhkan sebanyak 10 site. Dengan jumlah tersebut dihasilkan rata-rata RSRP sekitar -76.23 dBm, SINR rata-rata sekitar 21.6 $\mathrm{dB}$ dan throughput rata-rata sebesar 34.34 Mbps. Nilai-nilai tersebut sudah memenuhi standar KPI.Dari hasil analisis dan simulasi pada penelitian ini diharapkan menjadi bahan pertimbangan operator dalam meningkatkan performansi jaringan LTE di area tol Soreang Pasir Koja.

\section{DAFTAR PUSTAKA}

[1] Y. Yuan et al.2014. LTE-Advanced Coverage Enhancements. IEEE Communication Magazine. 153-159

[2] X. Y. Zhang, Y. Zhang, Y. M. Pan, and W. Duan. 2017.Low-profile dual-band filtering patch antenna and its application to LTE MIMO system.IEEE Trans. Antennas Propag.vol. 65 , no. 1 , pp. 103-113

[3] S. K. Jha, R. Rokaya, A. Bhagat, A. R. Khan, and L. Aryal.2017.LTE Network: Coverage and Capacity Planning 4G Cellular Network Planning around Banepa. 2017 Int. Conf. Netw. Netw. Appl., pp. 180-185

[4] W. Miao et al., "Coverage and Capacity Analysis of LTE-based Power Wireless Private Network.11th IEEE Int. Conf. Anti-counterfeiting, Secur. Identif, pp. 119-124

[5] N. Li, C. Huang, and M. Zhuang.2016.Performance Optimization and Simulation Verification of LTE Network Planning Based on Micro Coverage. Proceedings of ASID,pp. 126-130.

[6] L. Wardhana, B. F. Aginsa, A. Dewantoro, I. Harto, G. Mahardhika, and A. Hikmaturokhman.2014. 4G Handbook.

[7] D. Setiawan, D. Sirat, and D. Gunawan.2012. Feasibility of LTE $700 \mathrm{MHz}$ Digital Dividend for Broadband Development Acceleration in Rural Areas. J. ICT, vol. 6, no. 1, pp. 21-42

[8] V. L. F. Hermawan, A. Hikmaturokhman, and A. R. Danisya.2016. Perencanaan Jaringan Long Term Evolution (Lte)1800 Mhz Di Wilayah Magelang Menggunakan Bts Existing Operator Xyz. ProsidingSNST.

[9] T. Rappaport. 2002. Wireless communications: principles and practice.

[10] R. Nurhasanah and U. K. Usman.2017.Planning of LTE Network at Cawang - Cikarang Utama Toll Road with Adaptive Soft Frequency Reuse. Fifth Int. Conf. Inf. Commun. Technol. Plan. 